\title{
Necessity of Thrombophylaxis in Cushing's Syndrome
}

\section{Çiğdem TURA BAHADIR, Feyzi GÖKOSMANOĞLU, Elif KILIÇ KAN, Gülçin CENGIZ ECEMIŞ, Ayșegül ATMACA, Hulusi ATMACA, Ramis Çolak \\ Ondokuz Mayıs University School of Medicine \\ Department of Endocrionology and Metabolism \\ Samsun, TURKEY}

\section{OBJECTIVES}

\section{Cushing's syndrome (CS) is} accompanied by a 10 times increased risk of venous thromboembolism and arterial thrombosis. In this study we aimed to analyze frequency of thromboembolism in CS.

\section{METHODS}

We prospectively followed 62 patients who had been diagnosed with CS between 2010 and 2014 in our clinic. Of the patients, 60\% had Cushing disease (CD) (29 female, 8 male) and $40 \%$ had ACTH-independent CS (20 female, 5 male). Frequencies of arterial and venous thromboembolic events were recorded.

\begin{tabular}{|c|c|c|c|c|c|}
\hline \multicolumn{6}{|c|}{ Table 1: Location and time of thromboembolism in our patient population } \\
\hline \multirow[t]{2}{*}{ Age/Sex } & \multirow[t]{2}{*}{ Etiology of CS } & \multirow[t]{2}{*}{ Vessel } & \multirow{2}{*}{$\begin{array}{c}\text { Thromboembolic } \\
\text { event }\end{array}$} & \multicolumn{2}{|c|}{ Time of diagnosis } \\
\hline & & & & $\begin{array}{c}\text { Preoperative } \\
\text { period }\end{array}$ & $\begin{array}{c}\text { Postoperative } \\
\text { period }\end{array}$ \\
\hline $45-\mathrm{F}$ & Pituitary adenoma & venous & $\begin{array}{l}\text { DVT of lower } \\
\text { extremity }\end{array}$ & $\cdot$ & after 4 months \\
\hline 40-M & Pituitary adenoma & arterial & $\begin{array}{l}\text { Subacute thrombosis } \\
\text { of external iliac artery }\end{array}$ & - & after 1 week \\
\hline $42-M$ & Ectopic & arterial & Fatal PTE & Before 9 months & after 2 weeks \\
\hline \multicolumn{6}{|c|}{ DVT: deep venous thrombosis, PTE: pulmonary thromboembolism } \\
\hline
\end{tabular}

\section{RESULTS}

The prevalence of thromboembolic events was $5 \%$ in our patient population. Thromboembolism was diagnosed in three patients (2 CD, 1 ectopic CS); one with venous thromboembolism, two with arterial thrombosis (Table 1). Two of them were diagnosed in the postoperative period, but one of them was suspected to have the event before the surgery. Remaining one of the three patients was diagnosed with recurrent pulmonary thromboembolism both before and after surgery for CS.

\section{CONCLUSIONS}

Thromboembolism may occur before and after surgery in CS. It generally occurs in the first year, especially in the first three months following surgery. It may be venous or arterial in origin. Thus thromboprophylaxis should be administered to patients with active CS before and after the surgery for six months. 